\title{
Pengaruh Model Pembelajaran Generatif Terhadap Kemampuan Komunikasi Matematis Peserta Didik Kelas V Sekolah Dasar
}

\author{
Zutri Parwines ${ }^{1, *)}$, Meria Ultra Gusteti ${ }^{2, * *)}$ \\ ${ }^{1)}$ Program Studi Pendidikan Guru Sekolah Dasar, Universitas Adzkia \\ ${ }^{2)}$ Program Studi Matematika, Universitas Adzkia \\ ${ }^{*}$ Zutriparwines@ stkipadzkia.ac.id \\ ***)meria.u.g@stkipadzkia.ac.id
}

\begin{abstract}
The purpose of this research is to know the effect of learning model Generative on students mathematical ability. This research was conducted at SD Islam At-Taubah East Jakarta. The research design used is treatment by level $2 \times 2$, with independent variable is the learning model that is Generative and conventional (expository), dependent variable is mathematical communication ability. Sampling technique used random sampling. The result of this research is first learning Generative effective to improve student communication ability so that this model can be used by elementary school teacher in building material. Second, the learning model influences students' mathematical communication skills.
\end{abstract}

Keywords : Mathematical communication skill, Generative learning model.

(i) This is an open access article distributed under the Creative Commons 4.0 Attribution License, which permits unrestricted use, distribution, and eproduction in any medium, provided the original work is properly cited. $@ 2021$ by author

\section{PENDAHULUAN}

Matematika merupakan salah satu mata pelajaran di sekolah yang mendapatkan porsi perhatian terbesar baik dari kalangan pendi dik, orang tua maupun peserta didik. Banyak diantara orang tua yang memiliki persepsi bahwa matematika merupakan pengetahuan terpenting yang harus dikuasai peserta didik. Sayangnya, tidak semua peserta didik memi liki pengetahuan yang hebat di bidang mate matika. Bahkan banyak peserta didik yang beranggapan bahwa matematika merupakan pelajaran yang sulit dan menjadi hal yang paling menyeramkan.

Rendahnya hasil belajar matematika di In donesia dapat dilihat dari hasil AKSI/INAP 2016 yaitu 73,61 di tingkat international. Selanjutnya di tingkat nasional pembelajaran matematika masih sangat kurang, terlebih dalam hal literasi matematika. Analisis hasil AKSI menunjukkan perlunya peningkatan kemampuan peserta didik dalam mencari dan mengolah informasi. Selain itu, pembelajaran juga perlu lebih menekankan pada kemampu an analisis masalah sehingga dapat meningkat kan kemampuan peserta didik dalam meng identifikasi prosedur, konsep, atau rumus yang diperlukan untuk menyelesaikan soal. Se lain itu Programme for International Student Assessment (PISA) dan Trends In Inter national Mathematics And Science Study (TIMMS) tahun 2015. Hasil PISA dalam pembelajaran Matematika menunjukkan bah wa Indonesia menduduki urutan 62 dari 70 negara peserta yang ikut dengan hasil kompetensi matematika memperoleh rata-rata 386. Sedangkan hasil TIMSS 2015 me nunjukkan bahwa Indonesia menduduki urutan peringkat 44 dari 56 negara yang ikut dengan rata-rata 397 . Dengan hasil yang dicapai dalam pembelajaran matematika di Indonesia belum mencapai hasil yang maksimal.

Sesuai dengan visi dan tujuan dari doku men The National Council of Teachers of Mathe matics (NCTM, 2000) (Yulius, Irwan, and Yeri zon, 2017), yaitu Princples and Standards for School Mathematics, semua peserta didik harus mendapatkan kesempatan untuk mempelajari, mengapresiasi, dan mene rapkan keterampilan-keterampilan, konsepkonsep, dan prinsip-prinsip matematika baik di dalam ataupun di luar sekolah. Standar NCTM sebagai standar utama dalam pembe lajaran matematika yaitu kemampuan peme cahan masalah (problem solving), kemam puan komunikasi (communication), kemam puan koneksi (connection), kemampuan penalaran (reasoning), dan kemampuan repre senttasi (representation). Kelima standar 
tersebut mempunyai peranan penting dalam kurikulum matematika.

Berkaitan dengan harapan yang dibutuh kan dalam pembelajaran matematika, Sumarmo (2012) mengemukakan bahwa kemampuan komunikasi matematika meliputi kemampuan: menyatakan suatu situasi ke dalam bahasa matematik, simbol, ide, dan model matematika; menjelaskan dan memba ca secara bermakna, menyatakan, memahami, menginterpretasi, dan meng evaluasi suatu ide matematika dan sajian matematika secara lisan, tulisan, atau secara visual; mendengar kan, mendiskusikan, dan menulis tentang matematika; dan menyatakan argument da lam bahasanya sendiri (Helma, 2019)

Selain permasalahan komunikasi mate matis, berpikir kritis peserta didik juga perlu dilihat. Berdasarkan Badan Standar Nasional Pendidikan (BSNP) tahun 2006 merekomen dasikan bahwa dalam pembelajaran perlu diciptakan suasana aktif, kritis, analisis dan kreatif dalam pemecahan masalah. Pembe lajaran matematika sejatinya menumbuhkan kemampuan berpikir kritis, serta mengkomuni kasikannya sebagai aspek penting kecakapan hidup pembelajar (Munandar, 2009). Dalam matematika, tidak hanya pandai dalam hitung an saja tetapi yang lebih penting adalah bagaimana peserta didik mengerti tentang apa yang dihitung (Ardiansyah, Junaedi, dan Asikin, 2015). Pembelajaran matematika memiliki karakteristik yang sangat kompleks, sehingga berpikir kritis sangat diperlukan untuk melakukan analisis dalam mengkomuni kasikan pelajaran matematika (Filsaime. 2008). Kemampuan berpikir kritis peserta didik melibatkan kemampuan untuk membuat alasan yang masuk akal dalam situasi yang kompleks (Putri, Wiliandani, Hussen, dan Adawiyah, 2017). Berpikir kritis tersebut meliputi lima aktivitas, yaitu memberikan penjelasan sederhana, membangun keteram pilan dasar, menarik kesimpulan, memberikan penjelasan lebih lanjut, dan membuat strategi dan teknik (Gusteti, 2018).

Kenyataannya, berdasarkan hasil obser vasi di SD Islam At-Taubah dan SD Islam AtTaqwa bahwa pembelajaran matematika ini cenderung tradisional, yang antara lain dengan karakteristik: pendekatan lebih cende rung pada guru (teacher center), pendekatan yang digunakan lebih bersifat ekspositori, masih rendahnya pemahaman konsep. Hal ini terlihat saat peserta didik kurang dapat menyampaikan kembali pelajaran yang telah dipelajari, tidak bisanya membaca simbolsimbol yang ada pada pembelajaran mate matika. Hal ini juga dipertegas oleh guru mata pelajaran yang bersangkutan yaitu bapak Muroin sebagai guru mata pelajaran mate matika bahwa pada kenyataannya peserta didik sulit untuk mengkomunikasikan kem bali materi yang didapat. Kemampuan komunikasi peserta didik sulit untuk dilihat baik lisan maupun tulisan karena peserta didik identik hanya melihat dan mengikuti teman nya yang dianggap baik di dalam kelas. Selain itu, sedikit sekali bahkan jarang peserta didik yang bertanya maupun menjawab apa yang diinformasikan oleh guru. Apabila peserta didik terlibat aktif dalam proses belajar, mereka akan lebih mampu membangun gagas an, ide, dan konsep matematika, sehingga peserta didik akan memiliki konsep atas topik matematika tersebut. Selain itu, mereka juga dapat mengembangkan keterampilan-keteram pilannya.

Kemampuan komunikasi siswa perlu dikembangkan dalam pembelajaran mate matika. Untuk menumbuh kembangkan kemampuan komunikasi dalam pembelajaran matematika, guru harus berperan aktif untuk mengupayakan semaksimalnya dengan meng gunakan model-model pembelajaran yang akan mendorong peserta didik untuk melatih kemam puan komunikasinya. Untuk itu model pembelajaran yang dianggap cocok untuk meningkatkan kemampuan komunikasi mate matis adalah model pembelajaran generatif (Kurniasih, 2016). Kurniasih (2016) menyata kan pembelajaran generatif adalah model pembelajaran yang berlandaskan pada pan dangan kontruktivisme dalam belajar dan mengajar yaitu pandangan yang berpedoman pada asumsi dasar bahwa pikiran dibangun dalam asumsi peserta didik. Kedua, model pembelajaran memiliki fungsi sebagai instru ment yang membantu atau memudahkan peserta didik dalam memperoleh pengalaman belajar. Menurut Osborne dan Witrock model pembelajaran generatif terdiri dari empat fase pembelajaran yaitu fase eksplorasi, pemu satan, tantangan dan aplikasi.

Penyelesaian masalah kemampuan komunikasi matematis peserta didik dapat 
membantu siswa mengembangkan keteram pilan menyelesaikan masalah dan berpikir kritis. Model pembelajaran generatif merupa kan pembelajaran yang dapat meningkatkan kemampuan siswa untuk belajar karena siswa dilibatkan secara aktif dalam pembelajaran sehingga hal tersebut dapat meningkatkan kebermaknaan dalam pembelajaran. Berdasar kan hal tersebut, maka dilakukan penelitian dengan model pembelajaran generatif yang bertujuan membantu peserta didik untuk meningkatkan kemampuan komunikasi mate matisnya.

\section{METODE PENELITIAN}

Penelitian ini merupakan penelitian eks perimen. Populasi dalam penelitian ini adalah seluruh peserta didik kelas V di SD Islam At-Taubah Jakarta Timur tahun pelajaran 2017/ 2018 dan SD Islam AtTaqwa dengan mata pelajaran matematika dengan materi bangun ruang. Teknik pengambilan sampel dilakukan dengan Cluster Random Sampling. Peserta didik yang mengikuti mata pelajaran tersebut ter diri dari enam kelas. Dari enam kelas tersebut diambil dua kelas secara acak yaitu kelas VB dan VE, sedangkan untuk kelas VB terdiri dari 30 peserta didik dan kelas VE terdiri dari 30 peserta didik. Kedua kelas tersebut dipilih secara acak untuk menen tukan kelas eksperimen dan kelas kontrol, sehingga terpilih kelas VB sebagai kelas eksperimen yang mendapat pembelajaran generatif dan kelas VE sebagai kelas kontrol dengan pembelajaran ekspositori. Instrumen kemampuan komunikasi matematis berupa tes essay. Instrumen tersebut terdiri dari pengukuran soal ruang bangun. Instrument ini divalidasi oleh tiga ahli pendidikan matematika untuk melihat kesesuaian butir dengan indikator, kebenaran materi, konstruksi dan bahasa. Untuk menghitung validitas butir soal dilakukan dengan menggunakan product moment. Hasil uji validasi isi menunjukkan bahwa lima butir soal kemampuan komunikasi matematis tersebut valid. Instrumen tersebut dikatakan valid dengan keputusan bahwa $r$ hitung lebih besar dari $r$ tabel.

\section{HASIL DAN PEMBAHASAN}

Setelah dilakukan penelitian, data hasil penelitian dianalisis dan menunjukkan bahwa rata-rata skor kemampuan komunikasi mate matis peserta didik yang menggunakan model pembelajaran generatif sebesar 18 lebih tinggi, dibandingkan dengan yang mengguna kan pembelajaran konvensional. Hasil terse but dapat dilihat pada Tabel 1 .

Tabel 1. Kemampuan Komunikasi Matema tis Peserta Didik Menggunakan Model Pembelajaran Generatif (A1)

\begin{tabular}{lcc}
\hline Deskripsi & Generatif & Konvensional \\
\hline Mean & 13 & 10 \\
Modus & 15 & 9 \\
Median & 13 & 10 \\
Varians & 18,15 & 11,93 \\
Standar & 4,26 & 3,45 \\
Deviasi & & \\
Maximum & 20 & 16 \\
Minimum & 5 & 4 \\
\hline
\end{tabular}

Berdasarkan data skor frekuensi pada Tabel 1, model pembelajaran generatif dan kon vensional dapat dideskripsikan masingmasing ke dalam dua kelompok data, yaitu A1 dan A2 sebagai berikut.

1. Kemampuan Komunikasi Matematis pada Peserta didik yang Menggunakan Model Pembelajaran Generatif $\left(A_{1}\right)$

Berdasarkan hasil analisis data kemam puan komunikasi matematis peserta didik yang belajar menggunakan model pembe lajaran generatif sebanyak 60 peserta didik dijabarkan seba gai berikut. Perolehan skor tertinggi 20 , skor terendah 5, rata-rata 13 , nilai varians 18,5 dan simpangan baku (SD) 4,26. Untuk lebih jelas rangkuman deskripsi data kelompok tersebut disajikan dalam tabel distribusi frekuensi seperti pada Tabel 2.

Tabel 2. Skor Kemampuan Komunikasi Matematis Peserta Didik yang Belajar Menggunakan Model Pembelajaran Generatif $\left(\mathrm{A}_{1}\right)$

\begin{tabular}{cccccc}
\hline No & Skor & $\begin{array}{c}\text { Batas } \\
\text { Bawah }\end{array}$ & $\begin{array}{c}\text { Batas } \\
\text { Atas }\end{array}$ & $\mathbf{f}_{\mathbf{k}}$ & $\begin{array}{c}\mathbf{F}_{\mathbf{r}} \\
\mathbf{\%}\end{array}$ \\
\hline & 5 & & & & \\
1 & - & 7 & 4,5 & 7,5 & 7 \\
& 7 & & & & \\
2 & 8 & & & & \\
& - & 8 & 7,5 & 10,5 & 15 \\
\hline
\end{tabular}




\begin{tabular}{|c|c|c|c|c|c|}
\hline \multirow[b]{2}{*}{3} & 11 & \multirow[b]{2}{*}{9} & \multirow[b]{2}{*}{10,5} & \multirow[b]{2}{*}{13,5} & \multirow[b]{2}{*}{24} \\
\hline & $\begin{array}{c}- \\
13 \\
\mathbf{1 4}\end{array}$ & & & & \\
\hline 4 & $\begin{array}{c}- \\
16 \\
17\end{array}$ & 10 & 13,5 & 16,5 & 34 \\
\hline 5 & $\begin{array}{c}- \\
19 \\
20\end{array}$ & 4 & 16,5 & 19,5 & 38 \\
\hline 6 & - & 2 & 19,5 & 22,5 & 40 \\
\hline $\mathrm{Jml}$ & 40 & & & & 100 \\
\hline
\end{tabular}

Berdasarkan data pada Tabel 2, skor ke mampuan komunikasi matematis peserta didik yang belajar menggunakan model pembelajaran generatif tersebar pada enam kelompok kelas interval, yaitu skor persen tase tertinggi terdapat pada kelas interval 1416 sebesar $25 \%$ karena perolehan skor peserta didik terbanyak. Sedangkan, skor dengan persentase terendah terdapat pada kelas interval 20-22 dengan persentase 5\% kare na perolehan skor peserta didik paling sedikit.

Selanjutnya, dibuat histogram distri busi frekuensi skor kemampuan komunikasi matematis peserta didik yang belajar menggu nakan model pembelajaran generatif secara keseluruhan dapat dilihat pada Gambar 1 sebagai berikut.

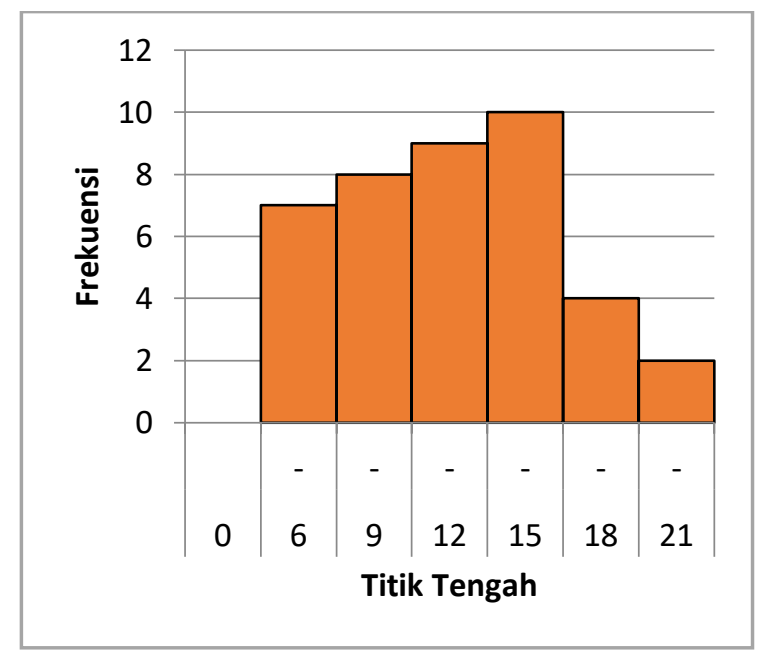

Gambar 1. Histogram Skor Kemampuan

Komunikasi Matematis Peserta didik yang Belajar Menggunakan Model Pembelajaran Generatif $\left(\mathrm{A}_{1}\right)$

2. Skor Kemampuan Komunikasi Matematis Peserta didik yang Belajar Menggunakan Model Pembelajaran Ekspositori $\left(\mathbf{A}_{2}\right)$
Berdasarkan hasil analisis data kemam puan komunikasi matematis peserta didik yang belajar menggunakan model pembe lajaran eks positori sebanyak 60 peserta didik dijabarkan sebagai berikut. Perolehan skor tertinggi 16, skor terendah 4 , rata-rata 10 , nilai varians 11,93 dan simpangan baku (SD) 3,45 . Untuk lebih jelas rangkuman deskripsi data kelompok tersebut disajikan dalam tabel distribusi frekuensi seperti pada Tabel 3.

Berdasarkan Tabel 3 skor kemampuan komunikasi matematis peserta didik yang belajar menggunakan model pembelajaran ekspositori tersebar pada tujuh kelompok kelas interval, yai tu skor persentase tertinggi terdapat pada kelas interval 12-13 sebesar $27,5 \%$ karena perolehan skor peserta didik terbanyak. Sedangkan, skor dengan persen tase terendah terdapat pada kelas interval 4-5 dan 16-17 dengan persentase 10,0\% karena perolehan skor peserta didik paling sedikit.

Selanjutnya, dibuat histogram distri busi frekuensi skor kemampuan komunikasi matematis peserta didik yang belajar menggu nakan model pembelajaran ekspositori secara keseluruhan dapat dilihat pada Gambar 2.

Tabel 3. Distribusi Frekuensi Skor Kemam puan Komunikasi Matematis Peserta Didik yang Belajar Menggunakan Model Pembelajaran Ekspositori $\left(\mathrm{A}_{2}\right)$

\begin{tabular}{|c|c|c|c|c|c|}
\hline No & Skor & $\begin{array}{c}\text { Batas } \\
\text { Bawah }\end{array}$ & $\begin{array}{c}\text { Batas } \\
\text { Atas }\end{array}$ & $\mathbf{f}_{\mathrm{k}}$ & $\mathrm{F}_{\mathrm{r}} \%$ \\
\hline 1 & $\begin{array}{l}4 \\
- \\
5\end{array}$ & 3,5 & 5,5 & 4 & 10 \\
\hline 2 & $\begin{array}{l}6 \\
- \\
7\end{array}$ & 5,5 & 7,5 & 9 & 12,5 \\
\hline 3 & $\begin{array}{l}8 \\
- \\
9\end{array}$ & 7,5 & 9,5 & 16 & 17,5 \\
\hline 4 & $\begin{array}{c}10 \\
- \\
11\end{array}$ & 9,5 & $\begin{array}{c}15 \\
5\end{array}$ & 23 & 17,5 \\
\hline 5 & $\begin{array}{c}12 \\
- \\
13\end{array}$ & 11,5 & $\begin{array}{c}16 \\
5\end{array}$ & 34 & 27,5 \\
\hline 6 & $\begin{array}{c}14 \\
- \\
15\end{array}$ & 13,5 & $\begin{array}{c}15 \\
5\end{array}$ & 36 & 5,0 \\
\hline 7 & $\begin{array}{c}16 \\
- \\
17\end{array}$ & 15,5 & $\begin{array}{c}17 \\
5\end{array}$ & 40 & 10,0 \\
\hline
\end{tabular}


Hasil penelitian yang tergambar pada Ta bel 2 dan Tabel 3 menunjukkan adanya perbeda an rentang nilai rata-rata kemampuan komunikasi matematis peserta didik menun jukkan bahwa terdapat perbedaan kemam puan komunikasi matematis peserta didik pada kedua kelas. Pernyataan ini didukung oleh hasil tempat pengujian. Dari hasil penelitian ini menunjukkan adanya perbedaan rata-rata rentang skor rata-rata kemampuan komunikasi matematis peserta didik menun jukkan bahwa terdapat perbedaan kemam puan komunikasi matematis peserta didik pada kedua kelas. Pernyataan tersebut didu kung oleh hasil tes menggunakan two-lane anova, membandingkan skor kemampuan komunikasi matematis peserta didik pada kelompok A1 dan A2 adalah 7,61 lebih besar dari 3,97 pada taraf kesalahan 0,05 dan skor pada kelompok A1 lebih ting gi dari kelompok A2. Artinya, skor kemampuan komunikasi matematis peserta didik yang menggunakan model pembelajaran generatif (A1) lebih tinggi daripada skor kemampuan komunikasi matematis peserta didik yang menggunakan pembelajaran ekspositori (A2) menjadi temuan pertama dalam penelitian ini. Hal ini menunjukkan bahwa pemberian model pembelajaran generatif lebih efektif mening katkan kemampuan komunikasi matematis peserta didik.

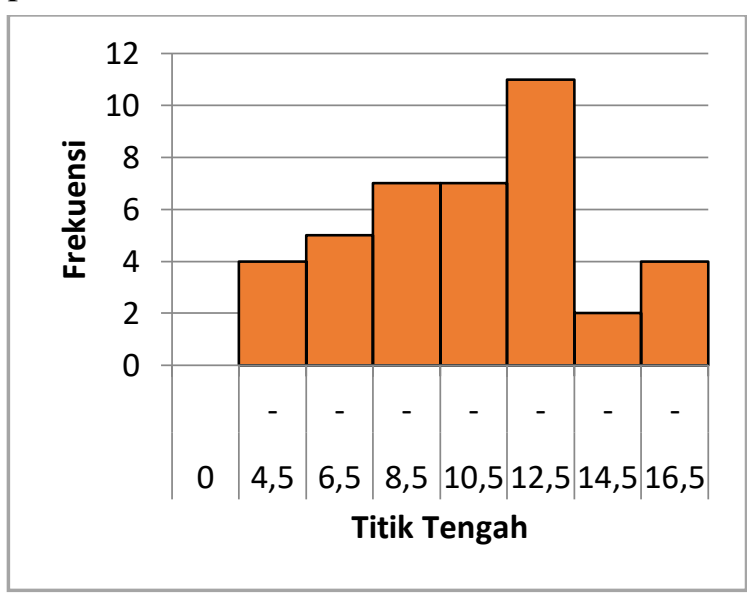

Gambar 2. Histogram Skor Kemampuan Komunikasi Matematis Peserta didik yang Belajar Menggunakan Model Pembelajaran Ekspositori $\left(\mathrm{A}_{2}\right)$

Telah diuraikan di atas bahwa penggu naan model pembelajaran yang generatif mampu mengembangkan kemampuan komu nikasi matematis peserta didik, karena mampu memberikan kesempatan kepada peserta didik untuk berinteraksi dalam menyampaikan ide, merefleksikan ide yang diberikan oleh teman nya dan berdiskusi dalam menyamakan yang memanfaatkan. empat tahapan (eksplorasi, pemfokusan, aplikasi) proses yang terjadi dalam kegiatan pembelajaran sehingga pembe lajaran sangat efektif dan mudah diikuti.

\section{KESIMPULAN}

Kemampuan komunikasi matematis merupakan kemampuan berpikir matematis tingkat tinggi yang penting bagi peserta didik. Model pembelajaran generatif meru pakan salah satu model pembelajaran yang akan membantu peserta didik meningkat kan kemampuan komunikasi matematisnya, dibandingkan dengan pembelajaran ekspo sitori. Berdasarkan hasil penelitian ini diharapkan guru dalam memberikan layanan pendidikan kepada peserta didik, tidak hanya memperhatikan hasil belajar, tetapi juga memperhatikan kemampuan matematika yang lebih tinggi. Guru juga diharapkan dapat menerapkan model pem belajaran generatif dalam proses kegiatan belajar mengajar, bagi kemampuan komu nikasi matematis peserta didik, yang juga akan berdampak pada peningkatan prestasi belajar peserta didik.

\section{DAFTAR PUSTAKA}

Ardiansyah, A, Iwan Junaedi, and Mohmmad Asikin. (2015). Eksplorasi Tingkat Ke mampuan Berpikir Kreatif Peserta didik Kelas VIII Pada Pembelajaran Matematika Setting Problem Based Learning. Prosiding Seminar Nasional Matematika IX 336-45

Muin, A and Isnaeni Fitri. (2012). Generative Model in Developing Mathematical Creative Thinking. Bandung: Proceedings of National Seminar Pasundan University

As'ari, A Rahman et al. (2016). Construct Variation in Mathematics Learning (ZDM, State University of Malang)

Baroody. Arthur J. (1993). Problem Solving, Reasoning, and Сотmu 
nicating, $\mathrm{K}-8$ Helping Children Think Mathematically. US A: Macmillan Publishing Company, 1993)

Filsaime, Dennis K. (2008). Revealing the Secrets of Critical and Creative Thinking. Jakarta: Achievement Publisher

Kesuma, Dharma et al. (2010). Contextual Teaching and Learning a Guide Preliminary In Development PBM. Jakarta: Rahayasa Research and Training

Gusteti, M. U., and Syafti, O. (2018). Pengaruh Pembelajaran Kontekstual dengan Teknik Hands on Mathematics terhadap Kemampuan Komunikasi Matematik Peserta Didik Kelas IX MTS Darussalam Kabupaten Pesisir Selatan. Jurnal Kepemimpinan dan Pengurusan Sekolah, 3(2), 217-225.

Helma, H. (2019). Penggunaan Flow Proof Pada Perkuliahan Analisis Real Untuk Meningkatkan Kemampuan Maha siswa Dalam Menganalisis Pembuk tian. Jurnal Eksakta Pendidikan (JEP), $3(1), 55-60$.

Kurniasih, M D. 2017. The Effect of Generative Learning on the Mathe matical Critical Thinking Thinking in Habit of Mind. (Journal of Mathe matics Education Vol. 2, No.1 2017).

OECD, PISA. 2015 Results: What Students Know and Can Do-Student Perfor mance in Mathematics, Reading and Science (PISA: OECD Publishing, 2016)

Putri, S. Wiliandani, I. Hussen, S. and Adawi yah, R. 2017. Kemampuan Berpikir Kreatif Dalam Menyelesaikan Masalah Kesebangunan Di SMPN 11 Jember. Jurnal Edukasi 4(3):59

Turmudi. The Foundation of Philosophy and Theory of Mathematical Learning with Explorative and Investigative Para digms. (Jakarta: PT Leuser Cita Pustaka, 2009)
Munandar. Utami 2009. Development of Gifted Children Creativity. Jakarta: Rineka Cipta.

Utari Sumarmo. 2012. Learning Materials Course Mathematical Thinking Process Master Program Education Mathe matics STKIP Siliwangi 2012. Bandung: STKIP Siliwangi.

Yulius, Benti, Irwan, and Yerizon. (2017). Pe ngembangan Perangkat Pembelajaran Matematika Berbasis Model Pembe lajaran Penemuan Dengan Masalah Open Ended Untuk Peserta Didik SMA Kelas X Semester 2. Mosharafa: Jurnal Pendidikan Matematika, 6 (2), 79-86. 